\title{
Implementasi Nilai Kebajikan Warga Negara (Civic Virtues) di Institut Teknologi Bandung
}

\author{
Ridwan Fauzi ${ }^{1}$, Prima Roza \\ Fakultas Seni Rupa dan Desain Institut Teknologi Bandung, Indonesia \\ 1ridwanelfawzy@gmail.com
}

\begin{abstract}
ABSTRAK
Pendidikan kewarganegaraan memiliki peran yang mendasar dalam pendidikan karakter multidimensi terutama untuk mengembangkan kompetensi kewarganegaraan. Kompetensi ini secara psikososial tercermin dalam pengetahuan kewarganegaraan (civic knowledge), sikap kewarganegaraan (civic disposition), keterampilan kewarganegaraan (civic skill), komitmen kewarganegaraan (civic commitment), dan keteguhan kewarganegaraan (civic confidence), yang semua itu memancar dan mengkristal menjadi kebajikan/keadaban kewarganegaraan (civic virtues). Salah satu peran mata kuliah PPKn adalah untuk meningkatkan warga negara yang lebih berkeadaban. Institut Teknologi Bandung (ITB) sebagai salah satu institusi pendidikan berbasis sains dan teknologi juga berperan dalam membangun karakter mahasiswa melalui mata kuliah PPKn. Tujuan dari penelitian ini adalah: pertama, untuk mengetahui hasil belajar mata kuliah PPKn di ITB; dan kedua, untuk menganalisis pelaksanaan mata kuliah PPKn dalam penanaman nilai-nilai kebajikan berdasarkan Pancasila. Metode yang digunakan dalam penelitian ini adalah kuantitatif deskriptif, dengan teknik pengambilan data yaitu survei di kelas PPKn di ITB. Hasil penelitian ini menunjukkan bahwa pembelajaran mata kuliah PPKn di ITB telah memberikan pengaruh yang signifikan untuk penanaman nilai-nilai kebajikan kepada siswa berdasarkan Pancasila. Pembelajaran ini juga memberikan pemahaman dan keterampilan yang dibutuhkan warga negara untuk siap berpartisipasi dalam mewujudkan kebajikan warga negara.

Kata kunci: Pendidikan Pancasila dan Kewarganegaraan, kecakapan kewarganegaraan, kebajikan warga negara, Institut Teknologi Bandung
\end{abstract}

\section{ABSTRACT}

Citizenship education (PPKn) has a very fundamental role in multidimensional character education particularly in developing civic competences, which are psychosocially reflected in civic knowledge, civic disposition, civic skills, civic commitment, and civic confidence, all of which radiate and crystallize into civic virtues. One of the roles of PPKn course is to promote more civilized citizens. Bandung Institute of Technology (ITB) as one of science and technology-based education institutions plays a role in building student characters through PPKn course. This study aims to: first, explain PPKn course learning outcomes at ITB; and second, analyze the implementation of PPKn course in internalising the virtues based on Pancasila. This study used descriptive quantitative approach. Data were collected by survey in ITB's PPKn classes. The result shows that PPKn learning at ITB has influenced significantly the cultivation of Pancasila-based civic virtues to the students. It also delivered the understanding and skills needed to participate in implementing the civic virtues.

Keywords: Pancasila and civic education, civic competences, civic virtue, Institut Teknologi Bandung 


\section{PENDAHULUAN}

Pendidikan nasional merupakan media pencerdasan kehidupan bangsa. Hal tersebut termaktub dalam pembukaan konstitusi Negara Republik Indonesia, Undang-Undang Dasar Negara Republik Indonesia Tahun 1945 alinea keempat dan pasal 31 "Tiap-tiap warga negara berhak mendapat pengajaran". Pelaksanaan pengajaran Pendidikan Kewarganegaraan (PKn) secara instrumental terdapat dalam Undang-Undang Nomor 20 Tahun 2003 tentang Sistem Pendidikan Nasional. Dalam Pasal 37 dijelaskan bahwa “...pendidikan kewarganegaraan dimaksudkan untuk membentuk peserta didik menjadi manusia yang memiliki rasa kebangsaan dan cinta tanah air." PKn di Perguruan Tinggi menjadi mata kuliah wajib yang diatur dalam Pasal 56 Undang-Undang Nomor 12 Tahun 2012 Tentang Pendidikan Tinggi. Lebih operasional lagi, menurut Pasal 4 Keputusan Ditjen Dikti Depdiknas RI Pasal 3 No. 267/DIKTI/2000 tentang Penyempurnaan Garis Besar Proses Pembelajaran Mata Kuliah Pengembangan Kepribadian (MKPK), PKn bertujuan untuk memberikan pengertian kepada mahasiswa tentang pengetahuan dasar berkenaan dengan hubungan antara warga negara dengan negara serta pendidikan pendahuluan bela negara sebagai bekal agar menjadi warga negara yang dapat diandalkan bangsa dan negara. Oleh karena itu, mata kuliah PKn mengemban misi khusus di Perguruan Tinggi.

Pendidikan kewarganegaraan juga memiliki peranan yang sangat fundamental dalam pendidikan karakter multidimensional. Karakter multidimensional itu meliputi pengembangan kecerdasan kewarganegaraan (civic intelligence) yang secara psikososial tercermin dalam penguasaan pengetahuan kewarganegaraan (civic knowledge), perwujudan sikap kewarganegaraan (civic disposition), penampilan keterampilan kewarganegaraan (civic skill), pemilikan komitmen kewarganegaraan (civic commitment), pemilikan keteguhan kewarganegaraan (civic confidence), penampilan kecakapan kewarganegaraan (civic competence), yang kesemua itu memancar dan mengkristal kembali menjadi kebajikan/ keadaban kewarganegaraan (civic virtue). Keseluruhan kemampuan itu merupakan pembekalan bagi warga negara untuk secara sadar melakukan partisipasi kewarga negaraan (civic participation) sebagai wujud tanggung jawab kewarganegaraan (civic responsibility) (Budimansyah, 2010; A. A. Wahab \& Sapriya, 2010).

Pendidikan Kewarganegaraan di Perguruan Tinggi dimaksudkan sebagai sarana pembinaan karakter bangsa (nation and character building). Dalam konteks yang berkaitan dengan kompetensi sosial, maka nilai-nilai yang dikembangkan mencakup harmoni diri (tanggung jawab, keyakinan pada ajaran agama, kepercayaan); harmoni sesama (penghargaan, kejujuran, kepedulian), serta harmoni alam (ramah lingkungan, melindungi). Sedangkan dalam konteks pengembangan nilai kebangsaan, Pendidikan Kewarganegaraan diorientasikan untuk mengungkap nilai-nilai kebenaran kehidupan berbangsa dan bernegara, yakni keberagaman budaya (Bhineka Tunggal Ika), nilai dasar berbangsa (Pancasila), nilai dasar bernegara (landasan konstitusional) UUD NRI Tahun 1945, dan keyakinan wujud negara kesatuan Indonesia (Mahpudz, 2015).

Memasuki abad ke-21, dunia internasional termasuk Indonesia mengalami 
berbagai macam perubahan. Hilangnya batas-batas antar negara menghasilkan warganegara global dan menjadikan manusia sangat bergantung kepada iptek. Perubahan yang begitu pesat juga mempengaruhi aspek kehidupan, politik, ekonomi, sosial, budaya dan aspek lainnya. Dalam hal ini Wahab dan Sapriya (A. Wahab \& Sapriya, 2011) mengungkapkan bahwa di antara ciri kehidupan pada era globalisasi adalah adanya persaingan (competition) di samping kerjasama (cooperation/collaboration). Hal itu menguatkan misi dan alasan untuk diajarkannya mata kuliah PPKn di sekolah ataupun di perguruan tinggi.

Tantangan tujuan pendidikan kewarganegaraan di perguruan tinggi dalam mewujudkan kehidupan demokratis yang disiapkan bagi mahasiswa perlu disesuaikan dengan perubahan paradigma pengajaran yang disesuaikan dengan kondisi yang dihadapi. Pengajaran pendidikan kewarganegaraan di perguruan tinggi harus memberikan solusi terhadap permasalahan yang telah disebut di atas, di mana Pendidikan Kewarganegaraan harus diorientasikan dalam rangka menumbuhkan daya saing bangsa Indonesia.

Institut Teknologi Bandung (ITB) sebagai insititusi berbasis sains dan teknologi terbaik di Indonesia tentunya dalam visinya mengupayakan lulusannya mampu berkontribusi positif dalam pembangunan bangsa Indonesia. Pelaksanaan pembelajaran Pendidikan Pancasila dan Kewarganegaraan (PPKn) di ITB merupakan mata kuliah wajib sarjana, di samping mata kuliah Agama dan Etika, dan mata kuliah Manajemen dan Lingkungan, masing-masing mempunyai 2 SKS. Mata kuliah PPKn termasuk mata kuliah wajib yang diberikan pada tahap sarjana untuk memenuhi Undang-Undang Nomor 20 Tahun 2003 tentang Sistem Pendi-dikan Nasional. Semua mahasiswa harus mengambil mata kuliah tersebut sebagai syarat kelulusan sarjana ITB. Bersama dengan mata kuliah Bahasa, PPKn dan Agama masuk dalam kelompok Mata kuliah Pengembangan Kepribadian (MPK), di mana hasil pendidikan mata kuliah tersebut diharapkan mengubah perilaku mahasiswa.

Di ITB, mata kuliah PPKn sebenarnya merupakan gabungan dua mata kuliah yaitu Pancasila dan Kewiraan yang menekankan pada bela negara, yang memberikan pengetahuan, pemahaman dan kemampuan dasar pada mahasiswa mengenai hubungan warganegara dan negara agar menjadi warganegara yang berkeadaban dan dapat diandalkan bagi bangsa dan negara. Tujuan pembelajaran PPKN di antaranya memberikan kepada mahasiswa (i) pemahaman konsep bernegara dan berbangsa sesuai dengan dasar negara Pancasila dan konstitusi negara, (ii) kecintaan terhadap negara sehingga siap untuk berbuat, melakukan pembelaan dan memberikan yang terbaik bagi bangsanya, dan (iii) kemampuan menganalisis dan memecahkan persoalan-persoalan yang dihadapi dalam kehidupan berbangsa dan bernegara.

Pelaksanaan perkuliahan PPKn disampaikan melalui metoda ceramah dan diskusi, baik dalam setiap pertemuan maupun dalam presentasi makalah yang dibuat secara berkelompok. Evaluasi perkuliahan dilakukan melalui ujian tulis untuk menilai tingkat pemahaman konsep bernegara dan bela negara, serta kehidupan berbangsa dan bernegara, dan melalui presentasi makalah kelompok terutama dalam upaya kelompok untuk mengusulkan solusi dari permasalahan yang diangkat dalam makalah. 
Penelitian Kokom Komalasari tentang pembelajaran PKn kontekstual berbasis living values education yang dimuat di Prosiding Seminar Nasional (Jurusan PKn UPI) pada tahun 2015 merupakan penelitian model pembelajaran dengan menggunakan pendekatan internalisasi nilai-nilai yang terjadi di lingkungan peserta didik dikaitkan dengan tujuan mata kuliah di lingkungan sekolah. Penelitiannya terbatas pada peserta didik di SMA. Kemudian penelitian selanjutnya yang dilakukan oleh Dikdik Baehaqi Arif mengenai Penguatan Kajian Akhlak Kewargaan (civic virtue) dalam Perspektif Islam dalam Masyarakat Multikultural. Penelitian ini membahas gagasan perlunya kajian penguatan akhlak kewargaan dalam memperkuat nilai hidup warga negara, namun kajian ini dibatasi pada pada nilai kebajikan dalam dimensi Islam. Adapun dalam penelitian ini adalah penanaman nilai-nilai kebajikan (civic virtues) dalam perspektif Pancasila dan lapangan penelitian dilakukan pada level mahasiswa di ITB sebagai perguruan tinggi yang didominasi oleh bidang science dan teknologi.

Berdasarkan permasalahan di atas, penelitian ini dimaksudkan untuk mendeskripsikan keberadaan mata kuliah PPKn di ITB beserta learning outcome-nya, mengkaji bagaimana penerapan nilai-nilai kebajikan (civic virtues) yang sesuai dengan nilai-nilai Pancasila berikut tantangan seperti apa yang dihadapi dalam mentransformasikan nilai-nilai tersebut. Penelitian ini hendak menganalisis keberadaan mata kuliah PPKn di ITB dan bagaimana proses pencapaian luarannya. Kemudian penelitian ini berupaya untuk menganalisis penerapan nilai-nilai kebajikan (civic virtues) berdasarkan Pancasila beserta upaya dalam menghadapi tantangan dalam pelaksanaan penanaman nilai-nilai kebajikan tersebut.

\section{METODE PENELITIAN}

Penelitian ini merupakan penelitian deskriptif kuantitatif. Pengambilan data dilakukan dengan survei terhadap mahasiswa ITB yang mengambil mata kuliah Pendidikan Pancasila dan Kewarganegaraan (KU/2071) pada semester satu tahun ajaran 2016-2017 yang berjumlah 1.850 mahasiswa. Penelitian ini dilaksanakan di kampus utama Institut Teknologi Bandung jalan Tamansari 10 Bandung. Adapun kurun waktu penelitian ini dilaksanakan pada bulan November-Desember 2016. Populasi penelitian ini adalah seluruh mahasiswa ITB yang mengambil mata kuliah

Pendidikan Kewarganegaraan (KU 2071), dengan sampel yang dipilih menggunakan teknik random sampling sebanyak 20 persen (361 orang) dari total 1850 mahasiswa.

\section{HASIL PENELITIAN}

\section{Learning Outcomes Mata Kuliah PPKn di ITB}

Mata kuliah PPKn di ITB berdasarkan pada landasan yuridis yang terdapat dalam UU No. 20 Tahun 2003 tentang Sistem Pendidikan Nasional, UU No. 12 Tahun 2012 tentang Peraturan Presiden Republik Indonesia Nomor 8 Tahun 2012 tentang Kualifikasi Nasional Indonesia (KKNI), SK Dirjen Dikti Np.43/Dikti/Kep/2006, Rambu-Rambu Pelaksanaan Mata Kuliah Pengembang Kepribadian di PT. Mata kuliah PPKn di ITB berada di bawah koordinasi Kelompok Keahlian Ilmu-Ilmu Kemanusiaan (KKIK) Mata Kuliah Umum (MKU) Fakultas Seni Rupa dan Desain ITB. Diterbitkannya Kerangka Kualifikasi Nasional Indonesia 
(KKNI) sebagai Peraturan Presiden Nomor 8 Tahun 2012, dan Undang-Undang Nomor 12 Tahun 2012 tentang Pendidikan Tinggi mendorong semua perguruan tinggi untuk menyesuaikan diri dengan ketentuan tersebut. KKNI merupakan pernyataan kualitas sumber daya manusia Indonesia yang penjenjangan kualifikasinya didasarkan pada tingkat kemampuan yang dinyatakan dalam rumusan capaian pembelajaran (learning outcomes).

Dengan adanya KKNI, rumusan kemampuan dinyatakan dalam istilah capaian pembelajaran (terjemahan dari learning outcomes), di mana kompetensi tercakup di dalamnya atau merupakan bagian dari capaian pembelajaran (CP). Penggunaan istilah kompetensi yang digunakan dalam pendidikan tinggi (DIKTI) selama ini setara dengan capaian pembelajaran yang digunakan dalam KKNI. Namun, karena di dunia kerja penggunaan istilah kompetensi diartikan sebagai kemampuan yang sifatnya lebih terbatas, terutama yang terkait dengan uji kompetensi dan sertifikat kompetensi, maka selanjutnya dalam kurikulum pernyataan kemampuan lulusan digunakan istilah capaian pembelajaran. Di samping hal tersebut, dalam kerangka kualifikasi di dunia internasional, untuk mendeskripsikan kemampuan setiap jenjang kualifikasi digunakan istilah learning outcomes.

Deskripsi capaian pembelajaran dalam KKNI mengandung empat unsur, yaitu unsur sikap dan tata nilai, unsur kemampuan kerja, unsur penguasaan keilmuan, dan unsur kewenangan dan tanggung jawab. Dengan telah terbitnya Standar Nasional Pendidikan Tinggi, rumusan capaian pembelajaran tercakup dalam salah satu standar yaitu Standar Kompetensi Lulusan (SKL). Dalam Standar Nasional Pendidikan Tinggi (SN-Dikti), capaian pembelajaran terdiri atas unsur sikap, keterampilan umum, keterampilan khusus, dan pengetahuan khusus di lingkungan Institut Teknologi Bandung (ITB). Learning outcomes diejawantahkan dalam bentuk student outcomes berdasarkan pada kriteria sistem ABET (Accreditation Board for Engineering and Technology). Adapun gambaran mengenai student outcomes tersebut dapat dilihat dalam Tabel 1.

\section{Tabel 1. Rubrik Mata Kuliah PPKn}

\begin{tabular}{|c|c|c|c|c|}
\hline & $\begin{array}{c}\text { STUDENT } \\
\text { OUTCOMES }\end{array}$ & $\begin{array}{l}\text { PERFORMANCE } \\
\text { INDICATORS }\end{array}$ & $\begin{array}{l}\text { TINGKAT } \\
\text { KOGNITIF }\end{array}$ & RUBRIK \\
\hline \multirow[t]{2}{*}{ A } & $\begin{array}{l}\text { Teamwork } \\
\text { (kemampuan } \\
\text { bekerja sama } \\
\text { dalam tim). }\end{array}$ & $\begin{array}{l}\text { Kemampuan } \\
\text { bekerja sama } \\
\text { dalam tim tanpa } \\
\text { memandang latar } \\
\text { belakang, } \\
\text { etnisitas, agama } \\
\text { dan status sosial } \\
\text { dalam } \\
\text { mencarikan } \\
\text { solusi terhadap } \\
\text { persoalan- } \\
\text { persoalan yang } \\
\text { dihadapi bangsa. }\end{array}$ & Aplikasi & $\begin{array}{l}\text { 4. Dalam pembuatan makalah kelompok } \\
\text { mampu memilih topik aktual, anggota tim } \\
\text { tanpa memandang latar belakang (agama, } \\
\text { etnis, status sosial, prodi), menghargai } \\
\text { pendapat yang berbeda, dan mampu } \\
\text { menghasilkan solusi yang aplikabel. } \\
\text { 3. Kemampuan memilih topik aktual, anggota } \\
\text { tim tanpa memandang latar belakang, dan } \\
\text { dalam diskusi menghargai pendapat yang } \\
\text { berbeda. } \\
\text { 2. Kemampuan memilih topik aktual dan } \\
\text { anggota tim tanpa memandang latar } \\
\text { belakang. } \\
\text { 1. Kemampuan memilih topik aktual. }\end{array}$ \\
\hline & & & & $\begin{array}{l}\text { Evaluasi: diskusi kelas, dengan kriteria } \\
\text { penilaian meliputi: }\end{array}$ \\
\hline
\end{tabular}




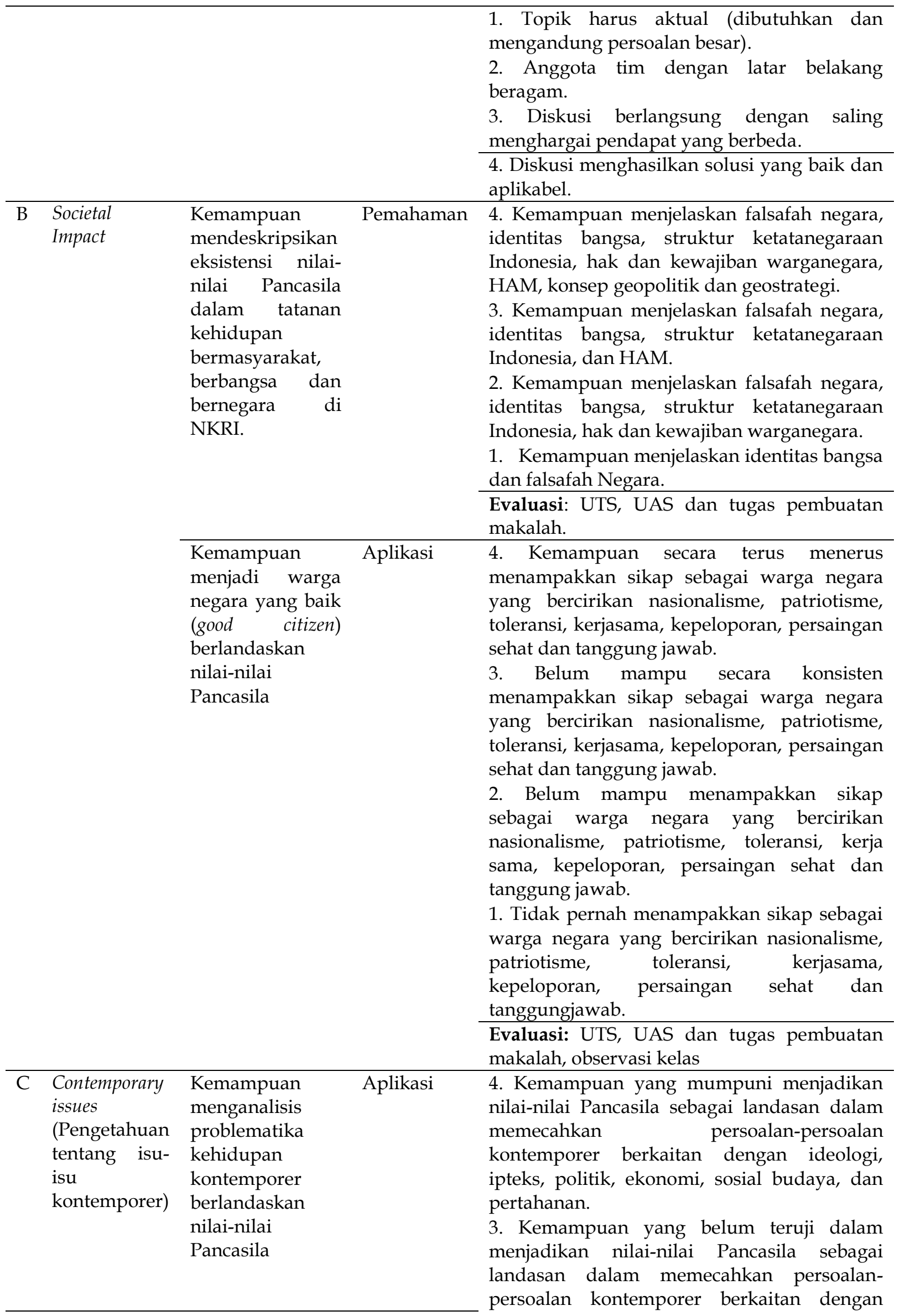


ideologi, ipteks, politik, ekonomi, sosial budaya.

2. Kemampuan yang masih lemah dalam menjadikan nilai-nilai Pancasila sebagai landasan dalam memecahkan persoalanpersoalan kontemporer berkaitan dengan ideologi, ipteks, politik, dan ekonomi, dan sosial budaya.

1. Kemampuan yang masih sangat lemah dalam menjadikan nilai-nilai Pancasila sebagai landasan dalam memecahkan persoalan-persoalan kontemporer berkaitan dengan ideologi dan politik, ekonomi, dan sosial budaya.

Evaluasi: UTS, UAS dan tugas pembuatan makalah, observasi kelas.

\section{Penerapan Nilai Kebajikan dalam Sila-Sila Pancasila}

Berdasarkan hasil kuesioner yang disebarkan pada kurun waktu NovemberDesember 2016 lalu, terhadap 361 mahasiswa dari 1850 yang mengambil mata kuliah PPKn di Institut Teknologi Bandung, dapat dijelaskan:

\section{Kebajikan Berketuhanan}

Penerapan nilai kebajikan berketuhanan tercakup dalam pertanyaan apakah mata kuliah PPKn ini telah sesuai dengan harapan mahasiswa bahwa memberikan dampak dalam mengembangkan kepribadian mahasiswa dalam penerapan nilainilai Pancasila. Sebanyak 19\% mahasiswa merasa bahwa mata kuliah PPKn berdampak melampaui harapan mereka. 60\% mahasiswa menjawab bahwa mata kuliah ini memenuhi harapan. Sebanyak $18 \%$ menjawab sebagian memenuhi harapan dan $2 \%$ tidak sesuai harapan.

Pertanyaan kedua adalah mengenai bagaimana pengaruh mata kuliah PPKn memberikan dampak positif terhadap kepribadian mahasiswa sebagai warga negara. Sebanyak 31\% mengatakan bahwa mata kuliah ini melampaui harapan mereka memberikan pengaruh positif terhadap kepribadian mereka. Kemudian sebanyak $48 \%$ menyatakan bahwa mata kuliah ini memenuhi harapan mereka. Dan sebanyak $19 \%$ mengatakan sebagian memenuhi harapan mereka dan $1 \%$ mengatakan tidak sesuai harapan.

\section{Kebajikan Berkemanusiaan}

Berdasarkan pertanyaan yang mengacu pada penanaman nilai kebajikan berkemanusiaan dapat dihimpun data berikut. Pertanyaannya adalah bagaimana dampak mata kuliah PPKn terhadap penanaman nilai keberagaman dan penanaman sikap toleransi mahasiswa. Sebanyak 33\% mengatakan bahwa mata kuliah ini telah melampui harapan mereka, sebanyak 49\% mengatakan mata kuliah ini telah memenuhi harapan mereka. Kemudian sebanyak $16 \%$ mengatakan sebagian memenuhi harapan mereka dan $2 \%$ mengatakan tidak sesuai harapan.

Pertanyaan kedua mengenai dampak mata kuliah PPKn terhadap peningkatan kesadaran dan kecintaan mahasiswa terhadap bangsa. Sebanyak 31\% 
mengatakan bahwa mata kuliah ini melampui harapan mereka. Sebanyak 49\% mengatakan dampak terhadap peningkatan kesadaran dan kecintaan terhadap bangsa memenuhi harapan mereka. Kemudian sebanyak 18\% sebagian memenuhi harapan mereka dan $2 \%$ mengatakan tidak sesuai harapan.

\section{Kebajikan Nasionalitas}

Berdasarkan pertanyaan yang mengacu pada nilai kebajikan nasionalitas dapat dihimpun data berikut. Pertanyaannya adalah bagaimana dampak mata kuliah PPKn dalam memberikan motivasi terhadap mahasiswa dalam memahami kondisi bangsa. Sebanyak 19\% mengatakan melampaui harapan mereka. Sebanyak 47\% memenuhi harapan mereka. Kemudian sebanyak 31\% mengatakan sebagian memenuhi harapan mereka dan sebanyak $4 \%$ mengatakan tidak sesuai harapan.

Pertanyaan kedua adalah mengenai dampak mata kuliah PPKn dalam meningkatkan kemampuan mahasiswa mendeskripsikan eksistensi nilai-nilai Pancasila dalam kehidupan bermasyarakat, berbangsa dan bernegara. Sebanyak 19\% mengatakan melampaui harapan mereka. Sebanyak 51\% memenuhi harapan mereka. Kemudian sebanyak 28\% mengatakan sebagian memenuhi harapan mereka dan sebanyak $2 \%$ mengatakan tidak sesuai harapan.

\section{Kebajikan Berkerakyatan}

Berdasarkan pertanyaan yang mengacu pada penanaman kebajikan berkerakyatan dapat dihimpun data berikut. Pertanyaan pertama adalah bagaimana dampak mata kuliah PPKn dalam memberikan kesempatan terhadap mahasiswa untuk lebih memantapkan pemahaman tentang konsep ketatanegaraan Indonesia. Sebanyak 27\% mengatakan melampaui harapan dan sebanyak 58\% mengatakan memenuhi harapan mereka. Kemudian sebanyak 13\% mengatakan sebagian memenuhi harapan dan $2 \%$ mengatakan tidak sesuai harapan.

Pertanyaan kedua bagaimana dampak mata kuliah PPKn dalam memberikan pemahaman yang lebih berarti terhadap mahasiswa tentang peran warga negara sebagai komponen negara demokratis. Sebanyak 21\% mengatakan melampaui harapan dan sebanyak $60 \%$ mengatakan memenuhi harapan. Kemudian sebanyak $17 \%$ mengatakan sebagian memenuhi harapan dan sebanyak 3\% mengatakan tidak memenuhi harapan.

\section{Kebajikan Berkeadilan}

Berdasarkan pertanyaan yang mengacu pada penanaman nilai kebajikan berkeadilan dapat dihimpun data berikut. Pertanyaan pertama bagaimana dampak mata kuliah PPKn dalam meningkatkan kemampuan mahasiswa untuk menjadi warga negara yang baik berdasarkan nilai-nilai Pancasila. Sebanyak 18\% mengatakan melampaui harapan mereka dan sebanyak 54\% mengatakan memenuhi harapan mereka. Kemudian sebanyak 25\% mengatakan sebagian memenuhi harapan, dan sebanyak 2\% tidak memenuhi harapan. Pertanyaan kedua mengenai dampak mata kuliah PPKn dalam meingkatkan kemampuan mahasiswa dalam menganalisis problematika kehidupan kontemporer berdasarkan nilai-nilai Pancasila. Sebanyak 20\% mengatakan melampui harapan dan sebanyak $48 \%$ memenuhi harapan. Kemudian sebanyak 29\% mengatakan sebagian memenuhi 
harapan dan sebanyak 3\% tidak memenuhi harapan.

\section{Tantangan Mata kuliah PPKn di Institusi Berbasis Sains dan Pendidikan}

Pengajaran mata kuliah PPKn di mana dalam hal ini peneliti menjadikan ITB sebagai model. Terdapat beberapa tantangan yang dihadapi dalam pelaksanaan mata kuliah ini.

Keberadaan mata kuliah PPKn di ITB sama halnya dengan kampus lain merupakan mata kuliah wajib mahasiswa, di mana mata kuliah ini memiliki bobot sebesar dua SKS. Mata kuliah ini berada di bawah naungan Kelompok Keahlian Ilmu Kemanusiaan Fakultas Seni Rupa dan Desain ITB. Di dalamnya terdapat prodi MKU yang mengorganisir semua mata kuliah umum, di antaranya; Agama dan Etika, PPKn, Bahasa Indonesia, Bahasa Inggris dan sejumlah mata kuliah pilihan. Adapun tantangan yang muncul dalam pelaksanaan mata kuliah ini di antaranya;

1. Kurangnya ketertarikan mahasiswa terhadap mata kuliah ini.

2. Jumlah mahasiswa yang banyak di dalam satu ruangan. Melebihi jumlah ideal dalam satu ruangan yakni sebanyak 40 mahasiswa. Sedangkan rata rata perkelas 70 mahasiswa.

3. Level kecerdasan mahasiswa di atas rata rata. Mayoritas mahasiswa yang masuk setelah melalui serangkaian seleksi ketat, dengan kata lain mereka yang telah masuk ke ITB merupakan hasil seleksi terbaik. Termasuk bagaimana mereka mahasiswa yang sangat mahir dalam bidang IT.

Pancasila memiliki peranan penting dalam tatanan kehidupan berbangsa dan bernegara. Pancasila menjadi inspirasi nilai yang baik yang digunakan sebagai pedoman kehidupan warga negara. Oleh karena itu, pemahaman dan penghayatan Pancasila patut dikedepankan dan diberlakukan sesuai dengan nilai-nilai luhur yang dikandungnya sehingga didapat satu persamaan persepsi dan kebenaran hakiki Pancasila (Prima, 2015).

Penanaman nilai kebajikan berketuhanan diantaranya tergambar dalam pertanyaan yang diajukan mengenai dampak mata kuliah PPKn sebagai mata kuliah yang menggambarkan kepribadian mahasiswa. Sebanyak 19\% mahasiswa mengatakan pengaruh mata kuliah ini dalam mengembangkan kepribadian mahasiswa melampaui harapan, sebanyak 60\% memenuhi harapan. Hal ini berarti bahwa secara kuantitatif pada umumnya mahasiswa mengatakan merasa puas. Hanya $18 \%$ yang mengatakan hanya sebagian memenuhi harapan dan $2 \%$ mengatakan tidak sesuai harapan. Kesimpulannya, mata kuliah PPKn telah mencerminkan sebagai mata kuliah yang menekankan pada aspek kepribadian.

Berkaitan dengan hal ini, Kanisius (2015) mengatakan bahwa kebajikan berketuhanan mencakup aspek kesadaran religiusitas dan kecerdasan spiritual untuk menjamin bukan saja kesejahteraan hidup ini, melainkan sekaligus kehidupan eskatologis atau masa depan. Kesadaran religiusitas tercermin dalam pengembangan aspek sikap (kepribadian). Dalam hal ini kaitan PPKn sebagai pengembang karakter kepribadian adalah memperkuat kompetensi nilai-nilai kehidupan. Nilai-nilai yang dikembangkan adalah kompetensi nilai harmoni yang mencakup; harmoni diri (tanggung jawab, keyakinan pada ajaran agama, kepercayaan); harmoni sesama (penghargaan, kejujuran, kepedulian), serta harmoni 
alam (ramah lingkungan, melindungi).

Adapun dampak mata kuliah PPKn terhadap kepribadian mahasiswa sebagai warga negara sebanyak 31\% mengatakan bahwa mata kuliah ini melampaui harapan mereka, dan memberikan pengaruh positif terhadap kepribadian mereka. Kemudian sebanyak 48\% telah memenuhi harapan mereka. Sebanyak 19\% mengatakan sebagian memenuhi harapan, dan 1\% mengatakan tidak sesuai harapan. Artinya, mahasiswa secara dominan mengatakan telah merasakan manfaat besar terhadap pengembangan kepribadian mereka sebagai warga negara. Hal ini senada dengan apa yang menjadi objek civic education yakni perilaku warga negara (Sapriya, 2013; A. Wahab \& Sapriya, 2011). Implikasi dari kebajikan berketuhanan yakni bagaimana warga negara memiliki hubungan yang baik secara vertikal terhadap Tuhannya dan kepada sesama manusia (horizontal). Warga negara yang memiliki kepribadian yang baik tersebut menggambarkan fungsi Pancasila yang termuat dalam mata kuliah PPKn sebagai sumber kepribadian bangsa Indonesia. Dalam hal ini Munir (2016) mendefinisikan kepribadian Indonesia sebagai keseluruhan ciri khas bangsa Indonesia yang membedakan dengan bangsa lainnya.

Mengenai kebajikan berkemanusiaan, Kanisius (2015) mengemukakan bahwa di dalam kebajikan berkemanusiaan terkandung ajaran untuk menghayati kehidupan sebagai satu kesatuan yang utuh, tak terpisahkan secara vertikal dan horizontal. Kebajikan ini mengajarkan kepada manusia untuk memandang manusia lain sebagai bagian integral dari dirinya.

Dampak dari penanaman nilai kebajikan berkemanusiaan tercermin dari pertanyaan yang diajukan mengenai dampak mata kuliah PPKn dan dampaknya terhadap penanaman nilai keberagaman dan penanaman sikap toleransi mahasiswa. Sebanyak 33\% mengatakan bahwa mata kuliah ini telah melampui harapan mereka, sebanyak 49\% mengatakan mata kuliah ini telah memenuhi harapan mereka. Kemudian sebanyak 16\% mengatakan sebagian memenuhi harapan mereka dan 2\% mengatakan tidak sesuai harapan. Secara mayoritas mata kuliah PPKn berdampak dalam mengajarkan makna toleransi terhadap mahasiswa. Dalam hal ini Kanisius (2015) mengelompokkan nilai toleransi sebagai bagian dari jenis kebajikan, sebagai dasar tanggung jawab dan muatan pendidikan kewarganegaraan, di mana kebajikan sivilitas dan toleransi sebagai sikap menghargai dan menerima orang lain karena keberlainannya. Menurut Tanuredja dalam sila kedua Pancasila terdapat nilai yang menjunjung tinggi nilai kemanusiaan, membela kebenaran dan keadilan, sadar bahwa manusia sederajat, karena itu dikembangkan sikap menghormati dan bekerja sama dengan bangsa lain (Tanuredja, 2013).

Kemudian implikasi dari penanaman nilai kebajikan berkemanusiaan tercermin dalam pertanyaan mengenai dampak mata kuliah PPKn terhadap peningkatan kesadaran dan kecintaan mahasiswa terhadap bangsa. Sebanyak 31\% mengatakan bahwa mata kuliah ini melampui harapan mereka. Sebanyak 49\% mengatakan dampak terhadap peningkatan kesadaran dan kecintaan terhadap bangsa memenuhi harapan mereka. Kemudian sebanyak 18\% sebagian memenuhi harapan mereka, dan $2 \%$ mengatakan tidak sesuai harapan. Secara mayoritas mahasiswa mengatakan mata kuliah ini telah memberikan pengaruh positif terhadap peningkatan kecintaan terhadap bangsa Indonesia. Hal ini sejalan dengan 
pendapat Munir (2016:148) bahwa di antara butir nilai yang terkandung dalam sila kedua Pancasila, di antaranya: mengakui persamaan derajat, persamaan hak, persamaan kewajiban antara sesama manusia, saling mencintai sesama manusia, berani membela kebenaran dan keadilan.

Kebajikan Nasionalitas sebagai nilai kebajikan dari Pancasila sila ketiga dalam penafsiran Kanisius (Kanisius, 2015) adalah kebajikan yang menegaskan pentingnya manusia untuk mengusahakan persatuan dan kesatuan sosial dan mondial seluruh umat manusia. Persatuan hanya mungkin tercapai apabila seluruh manusia Indonesia memiliki rasa memiliki terhadap bangsa dan tanah air, rasa persaudaraan terhadap sesama komunitas bangsa, rasa solidaritas dan toleran menyikapi keberagaman. Implikasi dari penanaman nilai kebajikan nasionalitas tercermin dalam pertanyaan yang diajukan mengenai bagaimana dampak mata kuliah PPKn dalam memberikan motivasi yang cukup terhadap mahasiswa dalam memahami kondisi bangsa. Sebanyak 19\% mengatakan melampaui harapan mereka. Sebanyak $47 \%$ memenuhi harapan. Kemudian sebanyak 31\% mengatakan sebagian memenuhi harapan, dan sebanyak $4 \%$ mengatakan tidak sesuai harapan. Secara umum mayoritas mahasiswa menjawab melampaui dan memenuhi harapan tentang pentingnya mata kuliah ini dalam memberikan motivasi memahami persoalan bangsa. Hal ini sebagai dampak kecintaan terhadap bangsa dan negara, sehingga mereka memiliki inspirasi untuk menjadi bagian dari pemecah masalah yang mungkin timbul terhadap bangsa saat ini. Hal ini selaras dengan apa yang dijelaskan Kanisius (2015) bahwa kebajikan semangat publik (public spirit) adalah kesanggupan untuk mengevaluasi kinerja yang sedang menjalankan tugas publik dan kerelaan untuk terlibat dalam wacana publik.

Selanjutnya implementasi nilai kebajikan nasionalitas tercermin dari pernyataan mengenai dampak mata kuliah PPKn dalam meningkatkan kemampuan mahasiswa mendeskripsikan eksistensi nilai-nilai Pancasila dalam kehidupan bermasyarakat, berbangsa dan bernegara. Sebanyak 19\% mengatakan melampaui harapan mereka. Sebanyak 51\% memenuhi harapan. Kemudian sebanyak 28\% mengatakan sebagian memenuhi harapan mereka dan sebanyak $2 \%$ mengatakan tidak sesuai harapan. Mayoritas mahasiswa menjawab merasakan dampak keberadaan mata kuliah PPKn terhadap kemampuan mahasiswa dalam mendeskripsikan eksistensi nilai-nilai Pancasila dalam kehidupan bermasyarakat, berbangsa dan bernegara. Mereka dituntut untuk menjadi solusi dalam menjawab berbagai tantangan dan persoalan bangsa, tentunya dengan berlandaskan nilai-nilai Pancasila. Hal ini diperkuat oleh pandangan Abdullah (2005) dalam upaya meminimalisasi konflik dengan penanaman kesadaran kepada masyarakat akan keragaman (plurality), kesetaraan (equality), kemanusiaan (humanity), keadilan (justice), dan nilai-nilai demokrasi (democratic values). Hal ini sejalan dengan pendapat Moeis (2014), untuk menjawab tantangan keberagaman bangsa dan menjaga keutuhan bangsa diperlukan kebajikan multikultural yang mencakup kekuatan jati diri, dialogis dan adil. Penguatan nilai kebajikan nasionalitas menekankan pada aspek penguatan watak dan karakter khususnya pengembangan watak yang menunjukkan aspek kecintaan terhadap bangsa dan negara yang dilandasi nilai persatuan dan kesatuan. 
Kebajikan berkerakyatan merupakan penanaman nilai kebajikan yang bersumber dari Pancasila sila keempat. Dalam hal ini Kanisius (2015) mengartikan kebajikan berkerakyatan adalah ajaran tentang pentingnya hidup berlandaskan pada asas kekeluargaan dan gotong royong. Diakui segala persoalan berbangsa dan bernegara bisa teratasi jika masyarakat berpegang pada kedua asas di atas secara arif dan bijaksana. Impilkasi nilai kebajikan berkerakyatan tercermin dari pernyataan mengenai bagaimana dampak mata kuliah PPKn dalam memberikan kesempatan terhadap mahasiswa untuk lebih memantapkan pemahaman tentang konsep ketatanegaraan Indonesia. Hal ini ditanyakan karena pemahaman warga negara akan konsep politik dan juga masalah kenegaraan terkait pula dalam sila keempat yang didalamnya terdapat penanaman nilai demokrasi. Dampak mata kuliah ini terhadap pemahaman mahasiwa akan konsep ketatanegaraan, tergambar dari $27 \%$ mengatakan melampaui harapan dan sebanyak 58\% mengatakan memenuhi harapan mereka. Kemudian sebanyak 13\% mengatakan sebagian memenuhi harapan dan $2 \%$ mengatakan tidak sesuai harapan.

Implementasi penanaman nilai kebajikan berkerakyatan juga tercermin dari pernyataan mengenai dampak mata kuliah PPKn dalam memberikan pemahaman yang lebih berarti terhadap mahasiswa tentang peran warga negara sebagai komponen negara demokratis. Sebanyak 21\% mengatakan melampaui harapan dan sebanyak $60 \%$ mengatakan memenuhi harapan. Kemudian sebanyak 17\% mengatakan sebagian memenuhi harapan dan sebanyak 3\% mengatakan tidak memenuhi harapan. Dari kedua peryataan di atas secara mayoritas mahasiswa menjawab mata kuliah PPKn berdampak pada pemahaman mereka akan konsep ketatanegaraan Indonesia dan peran mereka sebagai bagian dari negara demokratis Indonesia. Terciptanya kehidupan demokratis sebagai bagian dari tujuan bernegara di Indonesia juga sebagai misi dari diajarkannya mata kuliah PPKn di perguruan tinggi karena demokrasi haruslah terus ditransformasikan. Dalam hal ini Winataputra (2012) mengungkapkan bahwa demokrasi tidak bisa mengajarkan dirinya sendiri dan demokrasi memang bukan sesuatu hal yang diturunkan melalui proses kelahiran/keturunan, melainkan sesuatu yang harus dicerna melalui serangkaian proses belajar. Oleh karena itu. Sapriya (2013) mengungkapkan akan pentingnya penyelenggaraan pendidikan demokrasi secara terus menerus (continuous) dan berkesinambungan baik melalui lembaga persekolahan (school civic education) maupun lembaga masyarakat (community civic education). Sejalan dengan hal tersebut, Fauzi (2017) menjelaskan jika nilai-nilai demokrasi tumbuh dan berkembang dalam perilaku keseharian warga negara, maka akan tumbuh dan berkembang demokrasi yang mapan (established democracy). Hal ini pula diperkuat dalam kaitannya pendidikan dan demokrasi, menurut Tanuredja (2013) bahwa saai ini bangsa Indonesia sedang memasuki fase belajar berdemokrasi dalam berbagai aspek kehidupan di mana pendidikan merupakan pilar yang sangat penting sebagai penopangnya. Tanpa adanya pendidikan yang baik, sulit diharapkan demokrasi dapat lahir, dan berkembang dengan baik.

Nilai kebajikan yang terakhir yakni kebajikan berkeadilan sebagai nilai kebajikan yang bersumber dari Pancasila sila kelima. Kebajikan berkeadilan menegaskan pentingnya mengusahakan kehidupan yang adil, di mana terdapat 
pengakuan atas hak-hak dasar setiap manusia untuk mencapai kehidupan yang makmur dan sejahtera (Kanisius, 2015). Implementasi dari nilai kebajikan berkeadilan tercermin dari pernyataan mengenai bagaimana dampak mata kuliah PPKn dalam meningkatkan kemampuan mahasiswa untuk menjadi warga negara yang baik berdasarkan nilai-nilai Pancasila. Sebanyak 18\% mengatakan melampui harapan mereka dan sebanyak 54\% mengatakan memenuhi harapan. Kemudian sebanyak 25\% mengatakan sebagian memenuhi harapan mereka dan sebanyak $2 \%$ tidak memenuhi harapan. Pernyataan kedua mengenai dampak mata kuliah PPKn dalam meningkatkan kemampuan mahasiswa dalam menganalisis problematika kehidupan kontemporer berdasarkan nilai-nilai Pancasila. Sebanyak 20\% mengatakan melampui harapan dan sebanyak $48 \%$ memenuhi harapan. Kemudian sebanyak 29\% mengatakan sebagian memenuhi harapan dan sebanyak 3\% tidak memenuhi harapan.

Jawaban secara keseluruhan mengatakan dampak positif tentang adanya peningkatan kemampuan mahasiswa untuk menjadi warga negara yang baik dengan dilandasi nilai-nilai Pancasila. Hal ini munujukkan bahwa tujuan pendidikan kewarganegaraan sebagai mata kuliah pengembangan kepribadian (MKPK) yakni mahasiswa menguasai pengetahuan dan pemahaman tentang beragam masalah dasar kehidupan bermasyarakat, berbangsa dan bernegara yang hendak diatasi dengan penerapan pemikiran yang berlandaskan Pancasila, wawasan nusantara dan ketahanan nasional secara kritis dan bertanggung jawab Pasal 4 Keputusan Ditjen Dikti No 267/DIKTI/2000 tentang penyempurnaan Garis Besar Proses Pembelajaran Mata Kuliah Pengembangan Kepribadian (MKPK). Kemampuan lain sebagai implementasi dari kebajikan berkeadilan yakni kemampuan dalam memecahkan masalah terhadap permasalahan kehidupan kontemporer yang dilandasi nilai-nilai Pancasila. Secara umum mahasiswa merasakan dampak mata kuliah PPKn dalam kaitannya dengan kemampuan mereka menganalisis masalah kontemporer tersebut. Hal tersebut menjadi sebuah keniscayaan karena saat ini warga negara dituntut mampu menjadi problem solver (pemecah masalah) karena hari ini warga negara juga bagian dari warga global (global citizen). Dalam hal ini Aziz dan Sapriya (2011) mendefinisikan warga global sebagai warga yang memiliki semangat dan dorongan untuk memiliki perspektif global. Dalam perspektif lain hal ini menunjukkan akan peranan pendidikan kewarganegaraan dalam mentransformasikan pendidikan global sebagai upaya menanamkan pandangan (perspective) tentang dunia kepada para mahasiswa/siswa dengan memberikan pemahaman bahwa selalu terdapat saling keterkaitan antar budaya, umat manusia, dan kondisi planet di bumi ini. Pendidikan global juga ditujukan untuk mengembangkan pengetahuan (knowledge), keterampilan (skills) dan sikap (attitude) yang diperlakukan untuk hidup secara efektif di dunia (Murdiono, 2014).

Sejumlah upaya dalam merespon tantangan yang dihadapi dalam pengajaran mata kuliah PPKN di ITB, diantaranya: (a) sejumlah workshop dilakukan untuk menguatkan kapasitas dosen pengampu, seperti pengembangan model pembelajaran, system penilaian, dll. Hal tersebut dilakukan untuk memperkaya pengajar menyelenggarakan pengajaran dengan lebih variatif, bermakna dan efektif; 
(b) persiapan pengajaran yang lebih wajib dilakukan dosen, khususnya materi dan pendalamannya, mempersiapkan materi dan selalu terkait dengan keilmuan mahasiswa. PPKn dibahas pula dalam dimensi keilmuan mahasiswa. Hal tersebut senantiasa dilakukan untuk mengantisipasi permaslahan dan pertanyaan yang diajukan mahasiswa ITB yang sangat kritis; (c) menyelenggarakan pembelajaran berbasis IT, seperti membuka kelas webinar, kuis online, dan tugas online. Hal tersebut sangat merangsang mahasiswa melakukan pembelajaran dengan melibatkan teknologi yang menjadi salah satu identitas mahasiswa millennial; (d) menyesuaikan standar kurikulum PPKn dengan ABET sebagai akreditasi internasional. Sebelumnya telah dilakukan sejumlah pengkajian, workshop dan pelatihan untuk memenuhi slaah satu standar ini. Hal ini terimplementasi dari segi standarisasi materi, mutu soal, dan sistem evaluasi.

\section{SIMPULAN}

Mata kuliah PPKn di ITB berada di bawah koordinasi Kelompok Keahlian Ilmu-Ilmu Kemanusiaan (KKIK) dalam Mata Kuliah Umum (MKU) Fakultas Seni Rupa dan Desain ITB. Capaian pembelajaran (learning outcomes) mata kuliah PPKn di ITB disusun dan terdiri dari unsur sikap, ketrampilan umum, ketrampilan khusus, dan pengetahuan khusus di lingkungan Institut Teknologi Bandung (ITB). Learning outcomes diejawantahkan dalam bentuk student outcomes berdasarkan pada kriteria sistem ABET (Accreditation Board for Engineering and Technology).

Terdapat pengaruh yang signifikan dari pelaksanaan mata kuliah PPKn terhadap penanaman nilai kebajikan mahasiswa berdasarkan Pancasila, dan meningkatkan pengetahuan dan kompetensi mahasiswa sebagai warga negara dewasa untuk mampu menjadi pilar pembentukan negara demokratis. Tantangan yang dihadapi dalam pengajaran PPKn di ITB yakni rendahnya ketertarikan mahasiswa dalam mata kuliah ini, daya kritis mahasiswa yang tinggi, dan kemampuan yang dimiliki mahasiswa dalam penggunaan teknologi informasi. Untuk menjawab tantangan ini dilakukan sejumlah upaya seperti; melakukan workshop, memperbaiki rancangan pembelajaran, peningkatan penggunaan IT dan penyesuaian dengan standar ABET.

\section{REFERENSI}

Abdullah, A. (2005). Kesadaran Multikultural: Sebuah Gerakan "Interest Minimalization" dalam Meredakan Konflik Sosial. In M.A. Yaqin, Pendidikan Multikultural: Cross-Cultural Understanding untuk Demokrasi dan Keadilan (pp. xi-xx). Yogyakarta: Pilar Media

Fauzi, R. (2017). Pendidikan Demokrasi Dalam Perspektif Nahdlatul Ulama. Untirta Civic Education Journal. Vol 2, No 1 (2017)

Mahpudz, Asep. (2015). Pendidikan Kewarganegaraan di Perguruan Tinggi untuk Pengembangan Kesadaran Wawasan Kebangsaan dan Soft Skill Mahasiswa. Prosiding.hlm. 135

Munir, dkk. (2016). Pendidikan Pancasila. Malang: Madani Media

Moeis, Isnarmi (2014). Pendidikan Multikultural Transformatif; Integritas Moral, Dialogis, dan Adil. UNP Press 
Kanisius, Sylvester. (2015). Menanamkan Kebajikan Melalui Pendidikan Kewarganegaraan, Prosiding. Hlm. 504-507

Roza Prima \&dkk. (2015). Memahami dan Memaknai Pancasila sebagai Ideologi dan Dasar Negara. Jakarta: PT Gramedia Pustaka Utama

Sapriya. (2009) Pendidikan IPS. Bandung: Rosda Karya

Tanuredja, Tukiran. (2013). Konsep Dasar Pendidikan Kewarganegaraan. Yogyakarta: Penerbit Ombak

Tanuredja, dkk. (2016). Paradigma Terbaru Pendidikan Pancasila. Bandung: Alfabeta

Wahab, A. Aziz \& Sapriya. (2011). Teori dan Landasan Pendidikan Kewarganegaraan. Bandung: Alfabeta

Winataputra, Udin \& Alrakhman Riza. (2015). Pendidikan Pancasila dan Kewarganegaraan (PKn) untuk Generasi Emas Indonesia, Prosiding, hal. 3-4

Undang-Undang Dasar Negara Republik Indonesia Tahun 1945

Undang-Undang Republik Indonesia No. 12 Tahun 2012 Tentang Pendidikan Tinggi. Jakarta: Depdiknas, Ditjen Dikdasmen

Undang-Undang Republik Indonesia No. 20Tahun 2003 Tentang Sistem Pendidikan Nasional. Jakarta: Depdiknas, Ditjen Dikdasmen

Keputusan Ditjen Dikti Depdiknas RI N0 267 Tahun 2000 tentang Penyempurnaan Garis Besar Proses Pembelajaran Mata Kuliah Pengembangan Kepribadian (MKPK)

Peraturan Menteri No 22 Tahun 2006 tentang Standar isi

Peraturan Menteri No 23 Tahun 2006 tentang Standar Kompetensi Lulusan

Peraturan Presiden Republik Indonesia Nomor 8 Tahun 2012 tentang Kualifikasi Nasional Indonesia 